Short Communication

\title{
RISK FACTORS THAT DETERMINE LESS FAVOURABLE HOSPITALISATION COURSE AND OUTCOME IN PATIENTS WITH ESBL PRODUCING ENTEROBACTERIACEAE INFECTION: PRELIMINARY RESULTS
}

\author{
Vita Skuja ${ }^{1,2}$ \# , Katrīna Pekarska ${ }^{2}$, Una Caune ${ }^{3}$, Linda Piekuse ${ }^{4}$, Inga Kempa ${ }^{4}$, \\ Dace Rudzīte ${ }^{5}$, Dana Kigitoviča ${ }^{2}$, Aleksejs Derovs ${ }^{1,2}$, Ludmila Vỉksna ${ }^{1,6}$, \\ Aivars Lejnieks ${ }^{1,2}$, and Angelika Krūmiņa ${ }^{1,6}$ \\ ${ }^{1}$ Rīga East Clinical University Hospital, Hipokrāta iela 2, Rīga, LV-1038, LATVIA \\ 2 Department of Internal Medicine, Rīga Stradiṇš University, Dzirciema iela 16, Rīga, LV-1007, LATVIA \\ ${ }^{3}$ University of Latvia, Raina bulv. 19, Rīga, LV-1586, LATVIA \\ ${ }^{4}$ Scientific Laboratory of Molecular Genetics, Rīga Stradinš University, Dzirciema iela 16, Rīga, LV-1007, LATVIA \\ ${ }^{5}$ Bacteriology Laboratory, Rīga East Clinical University Hospital, Hipokrāta iela 2, Rīga, LV-1038, LATVIA \\ ${ }^{6}$ Department of Infectology and Dermatology, Rīga Stradinš̌ University, Dzirciema iela 16, Rīga, LV-1007, LATVIA \\ \# Corresponding author; vita@skuja.Iv
}

Communicated by Aivars Lejnieks

\begin{abstract}
Hospitalisation course and outcome for patients with extended-spectrum beta-lactamase (ESBL) producing Enterobacteriaceae infection is less favourable due to extensive antibacterial resistance. This study was conducted to identify possible risk factors that could influence the hospitalisation course and outcome in these patients. The study protocol included demographic, clinical, hospitalisation, bacteriological and plasmid genetic data. The preliminary study results showed that hospitalisation course and outcome was less favourable for internal medicine profile patients with ESBL producing bacteria, TEM gene presence in the bacterial plasmid genome, patient age $<65$ years and patients with infectious and musculoskeletal diseases. The study includes preliminary data only and further studies should be carried out to verify the suggested risk factors.
\end{abstract}

Key words: Enterobacteriaceae, ESBL, hospitalization, TEM, SHV.

Extended-spectrum beta-lactamase (ESBL) producing Enterobacteriaceae infection reports are increasing due to extensive antibiotic consumption and widespread ESBL bacterial gene - CTX-M, TEM and SHV mutation, determining bacterial, mostly $E$. coli and $K$. pneumoniae, resistance (Kim et al., 2002; Spanu et al., 2002; Thu Trang et al., 2013; Shaikh et al., 2015).

Hospitalisation course and outcome in patients with ESBL producing Enterobacteriaceae infection is considered less favourable due to extensive antibacterial drug resistance (Kim et al., 2002; Peralta et al., 2012). In order to choose the best empirical antibiotic therapy, physicians should look for factors that could indicate a less favourable hospitalisation course and outcome. An unfavourable hospitalisation course and outcome in patients with ESBL producing Enterobacteriaceae infection previously have been associated with severe concomitant diseases, prior administration of multiple antimicrobial agents, recent surgery, older age and presence of indwelling catheters (Skippen et al., 2006; Mehrgan et al., 2010).

The aim of this study was to identify additional possible risk factors that could influence the hospitalisation course and outcome in patients with ESBL producing Enterobacteriaceae infection. A cross-sectional single-centre study was conducted in Rīga East Clinical University Hospital. All consecutive ESBL producing Enterobacteriaceae infection cases were selected during a 6-month period (2014). A total of 136 ESBL producing Enterobacteriaceae infection cases were included in the study. Demographic, hospitalisation and clinical data were obtained from medical records on the day patient was discharged. Disease data were encoded according to the International Statistical Classification of Diseases (ICD-10) (Anonymous, 2015). Biomaterial (urine, bronchoalveolar washing, cerebrospinal fluid, wound swab, sputum, blood, abdominal cavity fluid, abscess sample) for bacteriological analysis was collected in transport medium 
and transported to the microbiological laboratory within 24 hours. In the laboratory, each sample was cultured. Identification of the bacteria was conducted by a Vitex 2 Compact system (bioMerieux, France) and susceptibility tests by the disk diffusion method (Oxoid, UK; CLSI 2013). ESBL production was confirmed using synergy tests with ESBL and Amp-C inhibiting discs (Rosco, Denmark). Genetic analysis provided information about CTX-M, TEM and SHV bacterial gene presence in the ESBL producing Enterobacteriaceae plasmid genome. Bacteria selected from ESBL producing Enterobacteriaceae colonies were grown in $2 \mathrm{ml}$ Lysogenic broth media at $37{ }^{\circ} \mathrm{C}$ overnight. Plasmid DNA were isolated by manufacturer protocol using a E.Z.N.A. plasmid Mini Kit I (Omega Bio-Tek, USA). CTX-M, SHV and TEM bacterial plasmid gene detection was performed using polymerase chain reaction (PCR) using gene specific primers (Wu et al., 2001; Edelstein et al., 2003; Anonymous, 2013). CTX-M gene detection was conducted according to Edelstein et al., 2003, SHV gene detection according to Nüesch-Inderbinen et al. (1996), and TEM gene detection according to Du et al. (2013). PCR products were analysed using 2\% agarose gel. A study protocol with 106 parameters was completed for each ESBL-producing Enterobacteriaceae infection case and used for database development and statistical analysis. All $p$ values were two-tailed and considered significant at the 5\% level. The study was conducted according to the Helsinki Declaration, reviewed and approved by the local Ethics Committee.

ESBL producing Enterobacteriaceae were isolated from 52 $(38.2 \%)$ female and $84(61.8 \%)$ male patients at the mean age of $61.35 \pm 16.92$ (CI 95\% 57.76-64.78) years. Mostly ESBL producing $K$. pneumoniae $(\mathrm{n}=66,48.53 \%)$ and $E$. coli $(\mathrm{n}=36,26.47 \%)$ were isolated (Fig. 1), mainly from wound ( $n=44,32.35 \%$ ) biomaterial (Fig. 2), in most of the cases $(n=132,97.06 \%)$ containing CTX-M gene (Fig. 3).

In 42 cases $(30.9 \%)$, ESBL-producing Enterobacteriaceae were isolated from internal medicine profile department patients, in 94 cases $(69.1 \%)$ from surgical profile department patients. Patients with ESBL producing Enterobacteriaceae infection spent an average of $60.29 \pm 98.93$ (CI 95\% 30.82-98) days in the hospital. In 82 ESBL producing Enterobacteriaceae infection cases $(60.29 \%)$ patients were admitted to the ICU at least once and time spent there was on average $18.57 \pm 21.9$ (CI 95\% 10.89-26.86) days. In 54 cases $(39.71 \%)$, patients were never admitted to ICU during their hospitalisation period.

Comparison between hospitalisation course and outcome in patients with ESBL producing Enterobacteriaceae infection in internal medicine and surgical departments is presented in Table 1.

TEM gene presence in ESBL producing Enterobacteriaceae plasmid genome was associated with increased mortality, compared to cases where the TEM gene was absent $(p=$ 0.018). CTX-M and SHV gene presence in ESBL producing Enterobacteriacea plasmid genome was not associated with a statistically significant increase in mortality.

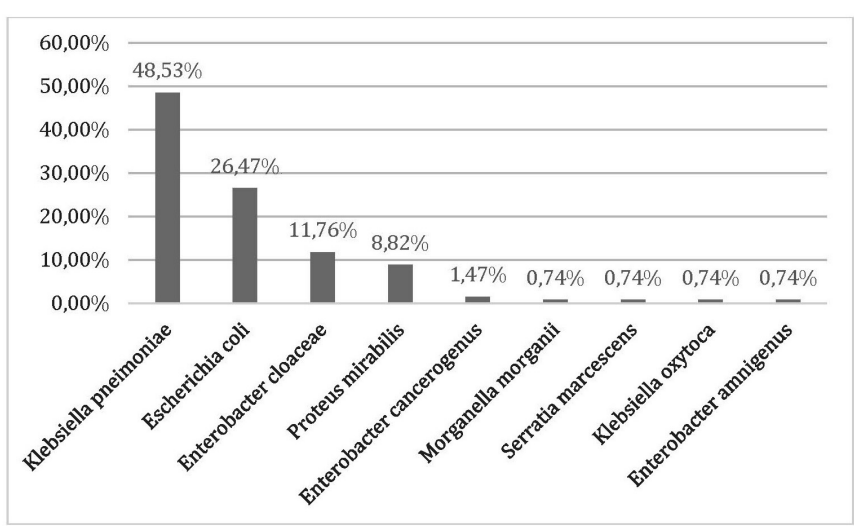

Fig. 1. Isolated ESBL producing Enterobacteriaceae strains (\%).

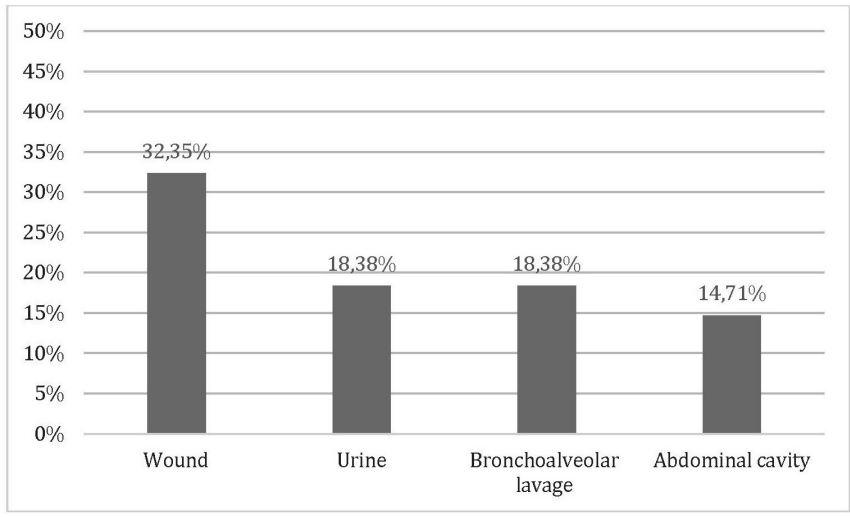

Fig. 2. Biomaterials from which ESBL producing bacteria were isolated $(\%)$.

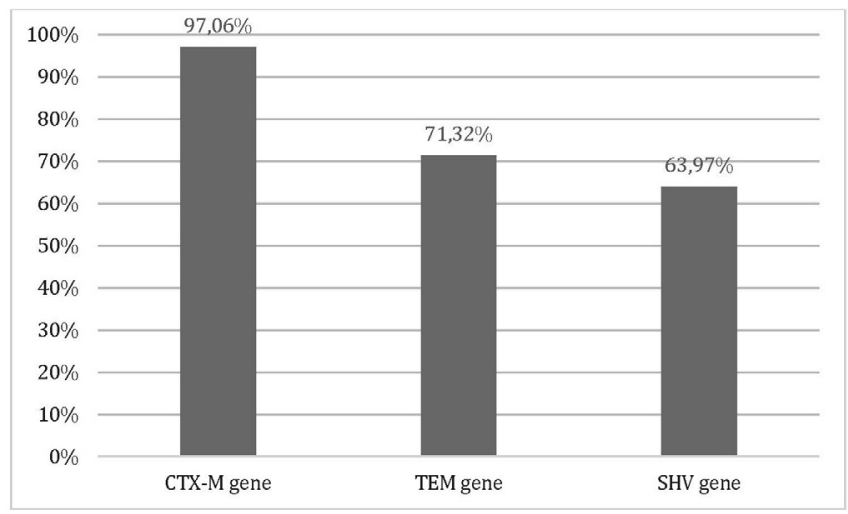

Fig. 3. Detected ESBL producing Enterobacteriaceae beta-lactamase plasmid genes $(\%)$.

Table 1

COMPARISON BETWEEN HOSPITALISATION COURSE AND OUTCOME IN PATIENTS WITH ESBL PRODUCING ENTEROBACTERIACEAE INFECTION IN INTERNAL MEDICINE AND SURGICAL DEPARTMENTS

\begin{tabular}{cc}
\hline Internal medicine department & Surgical department \\
\hline More concomitant diseases $(p<0.001)$ & More cases of sepsis $(\mathrm{p}<0.001)$ \\
More days spent in ICU $(p=0.043)$ & More cases of MODS $(p=0.001)$ \\
Increased mortality rate $(p=0.046)$ & Death at a younger age $(p=0.01)$
\end{tabular}


Patients with ESBL producing Enterobacteriaceae infection aged $<65$ years $(p=0.045)$ and concomitant infectious diseases $(p=0.047)$ were more frequently admitted to the ICU. Patients with ESBL producing Enterobacteriaceae infection admitted to the ICU $(p=0.02)$ and suffering from musculoskeletal diseases $(p=0.002)$ had increased mortality.

A less favourable hospitalisation course and outcome was observed in this study comparing to other literature sources: mean hospital stay was almost three times longer (60 vs 24 days) (Wu et al., 2014), patients were at least three times more often admitted to the ICU (60\% vs 4-23\%) (Concepts et al., 2010), stayed there almost two times longer (19 vs 12 days) (Abdalla et al., 2014) and had a higher mortality rate (21\% vs 14\%) (Peralta et al., 2012). This could be explained by the critically ill and immunocompromised patient predominance in the studied patient profile, including patients with severe abdominal trauma, head trauma, extremity amputations and extensive bedsores, suggesting a more severe clinical condition. Significantly more patients in this study presented with shock $(13 \%$ vs $6 \%)$ (Peralta et al., 2012) and were older (70 years) than patients described in the other literature sources (65 years) (Peralta et al., 2012).

Musculoskeletal disease presence, hospitalisation in internal medicine profile departments, and TEM bacterial gene presence were associated with increased mortality in this study and could be considered as possible risk factors for less favourable hospitalisation course and outcome for patients with ESBL producing Enterobacteriaceae infection. These factors have not been studied as possible risk factors in any studies previously. The CTM-X bacterial gene has been associated with increased mortality in patients with ESBL producing Enterobacteriaceae infection in other studies (Mehrgan et al., 2010); however, this association was not observed in our study. Concomitant infectious diseases and age less than 65 years predisposed patients with ESBL producing Enterobacteriaceae infection for more frequent admission to the ICU in this study. Admission to the ICU has been identified as a risk factor for increased mortality also in other studies (Mayr et al., 2006; Du et al., 2013). Therefore, infectious diseases and younger age might be considered as risk factors for a less favourable hospitalisation course and outcome for patients with ESBL producing Enterobacteriaceae infection.

The study includes preliminary data only and further studies should be carried out to verify the suggested risk factors.

\section{REFERENCES}

Abdalla, A. A. R. K., Mohamed, A. M. A. (2014). Prevalence of extended spectrum $\beta$-lactamase producing Klebsiella pneumonia in clinical isolates. Jundishapur J. Microbiol., 7, 1-5.

Anonymous (2013). EUCAST guidelines for detection of resistance mechanisms and specific resistances of clinical and/or epidemiological importance. Available at: http://www.eucast.org/fileadmin/src/media/
PDFs/EUCAST_files/Resistance_mechanisms/ EUCAST_detection_of resistance_mechanisms_v1.0_20131211.pdf (acessed 19.06.2016).

Anonymous (2015). WHO. International statistical classification of diseases and related health problems. ICD-10 Version. Available at:

http://apps.who.int/classifications/icd10/browse/2015/en (accessed 19.06.2016).

Concepts, C., Peleg, A. Y., Hooper, D. C. (2010). Hospital-acquired infections due to gram-negative bacteria. New Engl. J. Med., 362, 1804-1813.

Du, B., An, Y., Kang, Y., Yu, X., Zhao, M., Ma, X., Ai, Y., Xu, Y., Wang, Y., Qian, C., Wu, D., Sun, R., Li, S., Hu, Z., Cao, X., Zhou, F., Jiang, L., Lin, J., Chen, E., Qin, T., He, Z., Zhou, L. (2013). Characteristics of critically ill patients in ICUs in mainland China. Crit. Care Med., 41, 84-92.

Edelstein, M., Pimkin, M., Palagin, I., Edelstein, I., Stratchounski, L. (2003). Prevalence and molecular epidemiology of CTX-M extended-spectrumlactamase-producing Escherichia coli and Klebsiella pneumoniae in Russian hospitals. Antimicrob. Agents. Chemother., 47, 3724-3732.

Kim, B. N., Woo, J. H., Kim, M. N., Ryu, J., Kim, Y. S. (2002). Clinical implications of extended-spectrum beta-lactamase-producing Klebsiella pneumoniae bacteraemia. J. Hosp. Infect., 52, 99-106.

Mayr, V. D., Dünser, M. W., Greil, V., Jochberger, S., Luckner, G., Ulmer, H., Friesenecker, B. E., Takala, J., Hasibeder, W. R. (2006). Causes of death and determinants of outcome in critically ill patients. Crit. Care, $\mathbf{1 0}$ (6), R154

Mehrgan, H., Rahbar, M., Arab-halvaii, Z. (2010). High prevalence of extended-spectrum beta-lactamase-producing Klebsiella pneumoniae in a tertiary care hospital in Tehran. Iran J. Infect. Dev. Ctries., 4 (3), 132-138.

Nüesch-Inderbinen, M. T., Hächler, H., Kayser, F. H. (1996). Detection of genes coding for extended-spectrum $\mathrm{SHV}$ beta-lactamases in clinical isolates by a molecular genetic method, and comparison with the E test. Eur. J. Clin. Microbiol. Infect. Dis., 15, 398-402.

Peralta, G., Lamelo, M., Alvarez-García, P., Velasco, M., Delgado, A., Horcajada, J. P., Montero, M., Pia Roiz, M., Farinas, M. C., Alonso, J., Martinez, L. M., Gutierrez-Macias, A., Alava, J. A., Rodríguez, A., Fleites, A., Navarro, V., Sirvent, E., Capdevila, J. A. (2012). Impact of empirical treatment in extended-spectrum beta-lactamase-producing Escherichia coli and Klebsiella spp. bacteremia. A multicentric cohort study. BMC Infect. Dis., 12, 245-251.

Shaikh, S., Fatima, J., Shakil, S., Rizvi, S. M. D., Kamal, M. A. (2015). Antibiotic resistance and extended spectrum beta-lactamases: Types, epidemiology and treatment. Saudi J. Biol. Sci., 22, 90-101.

Skippen, I., Shemko, M., Turton, J., Kaufmann, M. E., Palmer, C., Shetty, N. (2006). Epidemiology of infections caused by extended-spectrum $\beta$-lactamase-producing Escherichia coli and Klebsiella spp.: A nested case-control study from a tertiary hospital in London. J. Hosp. Infect., 64, 115-23.

Spanu, T., Luzzaro, F., Perilli, M., Amicosante, G., Toniolo, A., Fadda, G. (2002). Occurrence of extended-spectrum beta-lactamases in members of the family Enterobacteriaceae in Italy: Implications for resistance to beta-lactams and other antimicrobial drugs. Antimicrob. Agents Chemother., 46, 196-202.

Thu Trang, N. H., Thieu Nga, T. V., Campbell, J. I., Hiep, N. T., Farrar, J., Baker, S., Duy, P. T. (2013). The characterization of ESBL genes in Escherichia coli and Klebsiella pneumoniae causing nosocomial infections in Vietnam. J. Infect. Dev. Ctries., 7, 922-928.

Wu, T. L., Siu, L. K., Su, L. H., Lauderdale, T. L., Lin, F. M., Leu, H. S., Lin, T. Y., Ho, M. (2001). Outer membrane protein change combined with co-existing TEM-1 and SHV-1 beta-lactamases lead to false identification of ESBL-producing Klebsiella pneumoniae. J. Antimicrob. Chemother., 47, 755-761.

Wu, Y. H., Chen, P. L., Hung, Y. P., Ko, W. C. (2014). Risk factors and clinical impact of levofloxacin or cefazolin nonsusceptibility or ESBL production among uropathogens in adults with community-onset urinary tract infections. J. Microbiol. Immunol. Infect., 47, 197-203. 
RISKA FAKTORI, KAS NOSAKA SLIKTĀKU HOSPITALIZĀCIJAS GAITU UN IZNĀKUMU PACIENTIEM AR ESBL PRODUCĒJOŠU ENTEROBACTERIACEAE DZIMTAS BAKTĒRIJU INFEKCIJU: SĀKOTNĒJIE REZULTĀTI

Hospitalizācijas gaita un iznākums pacientiem ar paplašināta spektra beta laktamāzi (ESBL) producējošo Enterobacteriaceae dzimtas baktēriju infekciju ir nelabvēlīgāks plašās antibakteriālās rezistences dēḷ. Šis pētījums tika veikts, lai noskaidrotu riska faktorus, kas varētu ietekmēt hospitalizācijas gaitu un iznākumu šiem pacientiem. Pētījuma protokols ietvēra demogrāfiskos, klīniskos, hospitalizācijas, bakterioloǵiskos un plazmīdu genētiskos datus. Pētījuma rezultāti parādīja, ka hospitalizācijas gaita un iznākums mazāk labvēlīgs bija terapeitiskā profila pacientiem ar ESBL producējošo baktēriju infekciju, TEM gēna klātbūtni baktēriju plazmīdu genomā, pacientiem vecumā zem 65 gadiem, kā arī pacientiem ar papildus infekcijas un balsta - kustību aparāta slimībām. Pētījums sniedz tikai sākotnējo informāciju — nepieciešami papildus pētījumi konstatēto riska faktoru izvērtēšanai. 